\title{
Use of Genomic Resources to Assess Adaptive Divergence and Introgression in Oaks
}

\author{
Desanka Lazic ${ }^{1}\left(\mathbb{D}\right.$, Andrew L. Hipp ${ }^{2}\left(\mathbb{D}\right.$, John E. Carlson ${ }^{3}$ and Oliver Gailing $1,4, * \mathbb{C}$ \\ 1 Department of Forest Genetics and Forest Tree Breeding, Georg-August University of Göttingen, \\ 37007 Göttingen, Germany; desanka.lazic@uni-goettingen.de \\ 2 Center for Tree Science, The Morton Arboretum, Lisle, IL 60532, USA; ahipp@mortonarb.org \\ 3 The Schatz Center for Tree Molecular Genetics, Pennsylvania State University, University Park, \\ State College, PA 16802, USA; jec16@psu.edu \\ 4 Center for Integrated Breeding Research (CiBreed), Georg-August University of Göttingen, \\ 37073 Göttingen, Germany \\ * Correspondence: ogailin@gwdg.de
}

Citation: Lazic, D.; Hipp, A.L.; Carlson, J.E.; Gailing, O. Use of Genomic Resources to Assess Adaptive Divergence and Introgression in Oaks. Forests 2021, 12, 690. https://doi.org/10.3390/ f12060690

Academic Editors: Mary Ashley and Janet R. Backs

Received: 30 April 2021

Accepted: 24 May 2021

Published: 27 May 2021

Publisher's Note: MDPI stays neutral with regard to jurisdictional claims in published maps and institutional affiliations.

Copyright: (c) 2021 by the authors. Licensee MDPI, Basel, Switzerland. This article is an open access article distributed under the terms and conditions of the Creative Commons Attribution (CC BY) license (https:/ / creativecommons.org/licenses/by/ $4.0 /)$.

\begin{abstract}
Adaptive divergence is widely accepted as a contributor to speciation and the maintenance of species integrity. However, the mechanisms leading to reproductive isolation, the genes involved in adaptive divergence, and the traits that shape the adaptation of wild species to changes in climate are still largely unknown. In studying the role of ecological interactions and environment-driven selection, trees have emerged as potential model organisms because of their longevity and large genetic diversity, especially in natural habitats. Due to recurrent gene flow among species with different ecological preferences, oaks arose as early as the 1970s as a model for understanding how speciation can occur in the face of interspecific gene flow, and what we mean by "species" when geographically and genomically heterogeneous introgression seems to undermine species' genetic coherence. In this review, we provide an overview of recent research into the genomic underpinnings of adaptive divergence and maintenance of species integrity in oaks in the face of gene flow. We review genomic and analytical tools instrumental to better understanding mechanisms leading to reproductive isolation and environment-driven adaptive introgression in oaks. We review evidence that oak species are genomically coherent entities, focusing on sympatric populations with ongoing gene flow, and discuss evidence for and hypotheses regarding genetic mechanisms linking adaptive divergence and reproductive isolation. As the evolution of drought- and freezing-tolerance have been key to the parallel diversification of oaks, we investigate the question of whether the same or a similar set of genes are involved in adaptive divergence for drought and stress tolerance across different taxa and sections. Finally, we propose potential future research directions on the role of hybridization and adaptive introgression in adaptation to climate change.
\end{abstract}

Keywords: Quercus; ecological speciation; genetic mosaic of speciation; introgression; reproductive isolation; species concepts

\section{Introduction}

Darwin's [1] account of the role of natural selection in speciation is arguably the most unifying principle in evolutionary biology. Yet remarkably, the mechanisms by which it may lead to reproductive isolation in the face of ongoing gene flow and the affected genes are still largely unknown [2-5]. Ecological speciation-the evolution of reproductive isolation between populations by adapting to different environments [2]—has in the past two decades become widely recognized as an important source of species diversity [6-10]. This perspective was accepted by many evolutionary biologists, building off the biological species concept even before evidence mounted in support of ecological speciation; but increasing evidence for environmental selection as separable from other divergence mechanisms [10] has rendered the concept of ecological speciation a unifier for 
speciation drivers as diverse as climate, resource competition, and predation [10]. It has become increasingly clear that the early focus on allopatric speciation, in which post-zygotic incompatibilities evolved in separated populations with no or limited gene flow [11,12], accounts for only a portion of the diversity of life $[3,13]$. To know the tree of life fully requires studying barriers to gene flow in populations that are not completely diverged and not yet reproductively isolated, before genetic changes contributing to reproductive isolation become confounded with other differences that accumulate after speciation [3].

One difficulty in studying genetic signatures of sympatric speciation has been technical: studying the maintenance of species integrity in the face of gene flow relies strongly on identifying enough molecular markers to tease apart the effects of genes that are driving divergence from those that are homogenized by gene flow [2,14-16]. Leaning on this concept of speciation in the face of gene flow, Via \& West [17] coined the term "genetic mosaic of speciation", based on evidence that divergent selection affects the genes of adaptive key traits while the rest of the genome can remain similar between species $[18,19]$. The related metaphor of "genomic islands of divergence" describes genomic heterogeneity in differentiation resulting from divergent selection $[8,20]$. Genomic regions under direct selection — the "islands" —or loci linked to them are expected to show signatures of relatively high interspecific differentiation in comparison to the genome as a whole. These "islands" form and then grow in size due to "divergence hitchhiking" [3,17], a reduction in gene flow in regions adjacent to selected genes that allows alleles involved in reproductive isolation to accumulate in the face of interspecific gene flow $[3,8,21]$. Due to divergence hitchhiking and a genomically localized reduction in interspecific gene flow, linkage disequilibrium is expected to be higher in those regions that are under divergent selection when compared to control regions $[3,14,15,17]$.

While the role of environmental selection in speciation is widely recognized, the genetic mechanisms linking adaptive divergence and reproductive isolation are still unclear [2,22-24]. The majority of adaptive divergence studies have been performed in model organisms $[25,26]$. Only a few "speciation" genes, especially causing hybrid inviability and sterility, have been identified, and mainly in model species [8,13,27-29]. As a consequence, little is known about the locations and distribution of regions/loci involved in adaptive divergence and reproductive isolation [30], especially in plants [24,29,31].

The high genetic diversity in tree species, especially in their natural habitats, makes them particularly well suited to research into adaptive divergence in response to changing environments [32]. There are other advantages to choosing trees as models for the study of genome-wide adaptive variation, including their limited history of domestication; their large, open-pollinated native populations [33]; their predominantly random mating systems; and their large effective population sizes [34]. Advances in next-generation sequencing technologies and bioinformatics in the last 15 years have greatly impacted our understanding of forest tree diversity and biology [35]. Tree genomics has benefited from the sequencing of several whole genomes [36-41], which have enabled studies of evolutionary history [32] and the potential roles of tens of thousands of genes on diversification, adaptation, and tree biology generally [35,38].

Oaks have long been recognized as important models for understanding ecological controls on speciation and gene flow, as edaphic and climatic factors shape patterns of distribution and introgression [42-46]. This may make oaks particularly well suited to understanding the genomic mosaic of introgression. A recent population genomic study using whole-genome sequencing in oaks has confirmed that divergence between hybridizing species is limited to a subset of the genome, maintaining species integrity in the divergent portions while the rest of the genome is permeable to gene flow: high levels of differentiation $\left(\mathrm{F}_{\mathrm{ST}}>0.8\right.$ ) were found at narrow regions distributed across the genome with an average width of $10 \mathrm{~kb}$, indicating that selection in these regions counteracts the homogenizing effect of gene flow [47]. In this context, a question of interest to our understanding of the longevity and persistence of species is whether species evolved in allopatry or sympatry, and whether and in which period there was potential gene flow 
between them, including whether introgression has been ongoing through the lifespan of the species or initiated after secondary contact [48]. Because divergent selection in strictly allopatric species proceeds unaffected by homogenizing effects of gene flow, the genetic mosaic is less pronounced in species that have diverged in allopatry [8]. In this respect, too, oaks present themselves as an ideal study subject, as the high diversity of oaks growing in sympatry across most of North America and much of western Europe and east Asia serve as replicated natural experiments in oak diversification. At an estimated 435 species, Quercus is one of the most diverse and most widespread woody plant genera in the northern hemisphere [44,49-52], and whole genomes of Quercus robur [53] and Q. lobata [54], as well as draft genome of $Q$. suber [41] position oaks as a model genus for understanding the evolution of reproductive isolation and divergence in the face of gene flow.

\section{Oaks as a Model to Study Adaptive Divergence between Species}

Oaks are important both economically and ecologically, not just for human use, but also as a shelter and food source for wild animals [55]. As far back as the colonization of early Homo sapiens of the Middle East and Europe [56], oaks are entangled in human history, symbolism, tradition, economics, and livelihoods [57-61]. Acorn findings in caves suggest that oaks fed humans in their early settlements and have long served as both a "famine food" and a chosen food, even when other options are available [59,62]. Oaks have also been valuable in cultural and religious life, from association with important gods (e.g., [58]) to becoming a national symbol for such modern countries as Germany, the UK, Poland, Portugal, and, in 2004, the USA [31]. In a review by Leroy et al. [31], the symbolism of oak trees and their significance for humans was connected with attributes of the oak genome. For example, longevity, cohesiveness, and robustness of oaks are three pillars on which the symbolism of oaks stands. As a genetic consequence of longevity, accumulation of heritable mutations is expected. However, Leroy et al. [31] summarized recent findings [38,63] that independently reported only small numbers of somatic mutations (17 and 46 singlenucleotide polymorphisms) at the whole-genome level. Their robustness was supported by Plomion et al. [38], revealing patterns of immune system diversification with an expansion of resistance (R) genes accounting for $9 \%$ of the gene catalogue [31]. Thus, the importance of oaks to humans is deeply rooted in their diversification history and biology.

Oaks have been described as a thorny problem [31] and a "worst case scenario" for the biological species concept [13], and they have been included among "botanical horror" taxa [64]. Oaks are problematic for classical biological or morphological species concepts because of weak interspecific boundaries and high intraspecific variation relative to interspecific differentiation [65-70]. Due to these observations, it has been suggested that speciation in oaks may be driven by ecological factors, as reflected in their occurrence in different micro-environments, rather than by strong post-zygotic reproductive isolation [71,72]. Oaks, however, are not unique in the difficulties they pose for delimiting species in light of hybridization. They do exhibit introgression, but many other taxa do as well. Perhaps more important is the fact that oaks are particularly well studied and extremely rich in species, with many occurring in sympatry and thus subject to multispecies introgression [42,73]. Oaks are, for these reasons, among the most famous syngameons (groups of species that maintain their distinctions despite sympatry and regular introgressive hybridization [73-76]).

\section{The Reality of Oak Species and Oak Introgression}

Species boundaries in oaks are often genetically and morphologically ambiguous $[55,66,77,78]$. Still, different species typically form genetically disjunct clusters [66,78-83] and maintain ecological distinctions, with ecologically divergent oaks commonly growing together in the same forest but in different micro-environments [84-87]. Oaks hybridize readily within sections, but hybrids between different sections are exceptionally rare in botanical gardens and have not been recorded in nature $[55,88,89]$, though ancient introgression has been detected between sections Quercus and Ponticae [90] and sections Quercus and Protobal- 
anus [91,92]. Good examples of species pairs that occur in sympatry but differ in local adaptations (for example to drought) include Q. rubra and Q. ellipsoidalis in North American red oaks (section Lobatae), Q. robur and Q. petraea in European white oaks (section Quercus) [93-95], and Q. virginiana and Q. geminata in the North American live oaks (section Virentes) [96]. These and many other species pairs are known to hybridize where their ranges overlap $[70,77,97,98]$, with introgression shifting over time in many cases as climate and habitats change $[45,46,99]$. Assessing levels of hybridization is necessary in studying the effects of interspecific gene flow and divergent selection of species [100].

Until the 1980s, hybrids were characterized purely based on morphological characteristics such as leaf morphology $[67,101-106]$, and later based on genetic markers that helped distinguishing species of the same taxonomic section $[81,100,107,108]$. Some studies have combined morphometric and molecular approaches to identify hybrids $[68,109-111]$. While understanding morphological and functional variation in combination with molecular variation is key to understanding how introgression shapes species evolution and ecology, molecular genetic markers are more useful for identifying hybrids and quantifying introgression, because molecular markers generally show higher discriminatory power and accuracy in species assignment than morphological characteristics and directly sample the genomic background that is most often the target of studies.

Hybridization rate and introgression can be estimated based on identification of hybrids and introgressive forms across species ranges or in sympatric stands using genetic assignment analyses in adult trees, seeds or seedlings; or using paternity analysis, which is limited to sympatric stands [89]. In either case, analyses are based on species-discriminating markers (fixed or nearly fixed within species; e.g., [75,112] or markers polymorphic in all species (e.g., [113])). Several studies of contemporary interspecific gene flow using paternity analysis have been conducted in multi-species stands of European white oaks $[98,114,115]$. A comparatively high level of interspecific gene flow and introgression was found in the contact zone of species in each example. Using a set of six polymorphic microsatellite loci and paternity analysis in 320 acorns from four oak species, Curtu et al. [98] found an overall hybridization rate of $35.9 \%$, with first generation hybrids present at a rate of $8.4 \%$. Similarly, by means of paternity analysis, a comparable rate of $F_{1}$ hybrids $(9.0 \%)$ was found in 623 acorns by Lepais and Gerber [114] using 10 microsatellite markers in four oak species. Comparable overall proportions of hybrids between Q. petraea and Q. pubescens $(26 \%)$ were revealed by paternity analysis of acorns by Salvini et al. [115]. Microsatellite markers were used also in contemporary gene flow studies in North American oaks [70,77]. Paternity analysis of $Q$. coccinea, $Q$. rubra, Q. velutina and $Q$. falcata demonstrated more than $20 \%$ of seedlings in two mixed-species stands to be potential hybrids [70]. Interspecific gene flow was also confirmed by Khodwekar and Gailing [77] based on parentage analysis of 466 seeds collected from 15 genetically assigned seed parents in sympatric stands of Q. rubra and Q. ellipsoidalis, which revealed that $3.9 \%$ of the seedlings $(0-25 \%$ for individual seed parents) were derived from interspecific matings.

Genetic assignment analyses are more commonly used to estimate introgression rates. Analyzing five nuclear microsatellite markers with both multivariate discriminant and Bayesian clustering methods implemented in STRUCTURE [116], Valbuena-Carabana et al. [87] quantified genetic differentiation and introgression in 176 adult trees of Q. petraea and Q. pyrenaica. They found reliable minimum estimates of introgression between species to be relatively low, identifying only $8.5 \%$ of adult trees as putative first and later generation hybrids. Similar results were found in a Romanian oak stand comprising the four interfertile species Q. petraea, Q. robur, Q. pubescens, and Q. frainetto [80]. Using genetic assignment analysis in adult trees, introgression rates between pairs of species varied, with the highest value between $Q$. pubescens and $Q$. frainetto $(16.2 \%)$ and the lowest value between $Q$. robur and $Q$. frainetto $(1.7 \%)$. Comparatively low percentages of adult trees $(2.1 \%-4.6 \%)$ and acorns $(1.5 \%)$ with hybrid ancestry were found in mixed stands of $Q$. lobata and Q. douglasii $[108,117]$. While hybrids are often comparatively frequent in direct contact zones of interfertile species, they rarely occur in pure stands (e.g., [81]). Despite this preponderance 
of gene-conduits in the contact zones of species, we still observe long-term maintenance of species. A range-wide study of four interfertile oak species-Q. ellipsoidalis, $Q$. coccinea, $Q$. rubra, and Q. velutina-demonstrated that genetically intermediate individuals or putative $\mathrm{F}_{1}$ hybrids were present in contact zones between species, where they were inferred to act as a bridge for recurrent gene flow [83]. The same four species were studied by Zhang et al. [118] using maternally inherited chloroplast DNA markers for the first time in red oaks. At three chloroplast microsatellite markers, a total of 23 haplotypes were observed. In all cases, neighboring interspecific population pairs shared haplotypes, indicating contemporary interspecific gene flow. Using a set of 58 unlinked SNPs from coding regions, Reutimann et al. [65] assessed the extent of admixture in three presumably mixed populations of the white oak species $Q$. robur, Q. petraea, and $Q$. pubescens across Switzerland. The Bayesian STRUCTURE method and a machine learning approach (support vector machine) recovered admixture levels of 35-36\%. Levels of admixture varied across the species pairs, but the highest degree was detected in mixed stands of $Q$. petraea and $Q$. pubescens, indicating high levels of gene flow between these two species. Since no fixed alleles were recovered in any of the taxa, levels of interspecific heterozygosity could not be quantified. This may be a general issue in oaks, in which pure stands (lacking admixture) and fixed alleles are nearly impossible to find (though cf. [112], in which apparently fixed SNPs were identified using RAD-seq and then used to genotype range-wide samples in [75]).

The weight of evidence thus demonstrates two important facts. First, oak species cohere genetically. When DNA data are directed at oaks, for the most part they are found to cluster in genetic space (going back to the foundational study of [119]). The published exceptions we are aware of (e.g., $[70,120,121])$ involve relatively small numbers of microsatellites, and studies using larger numbers of markers on the same taxa (e.g., [66,75]) have generally found the species to separate in molecular genotypic space. Second, numerous studies (cited in paragraphs above) demonstrate that introgression is ongoing at a fairly high rate, and consequently that conduits for gene flow between species may be present on the landscape at rates of $9-20 \%$ or higher, depending on the species pair. Assuming that these rates are representative of the long-term histories of gene flow between oak species, these two findings in combination strongly suggest that oaks cohere genetically in spite of ongoing gene flow. Thus, the data support the existence of a syngameon of interconnected oak species, evolving both separately and together, as hypothesized in the mid-1970s [71,72].

\section{Evidence for Selection against Hybrids}

While the number of hybrids and introgressive forms seems to be low in adult trees $[80,81,87,89]$, gene flow analyses suggest frequent interspecific gene flow $[70,78,98,115]$, which may suggest selection against hybrids from seedling to adult stage. Thus, Curtu et al. [98] found a much higher proportion of hybrids in the seed generation as determined by paternity analysis (35.9\%) when compared to the adult trees $(20.1 \%)$ in a multi-species oak stand, suggesting selection against many or perhaps most hybrid genotypes may be a mechanism for the maintenance of species identity. On the other hand, Abraham et al. [117] found low numbers of hybrids in both adults $(2.1 \%)$ and acorns $(1.5 \%)$ in $Q$. lobata and $Q$. douglasii stands. It is important to note that these observational studies cannot distinguish between selection and stand-level historical changes in species composition and structure, climate, or management that might result in inter-generational differences in introgression rate. While they are strongly suggestive, direct evidence of selection against hybrids would require the assessment of hybrids and parental species over time, ideally from seed to juvenile and adult stage. To our knowledge, such long-term experiments have not been performed yet. In their absence, the sum of observational studies in independent mixed-oak stands showing consistently higher introgression rates in the acorn/seedling generation relative to the adults nonetheless gives credence to the hypothesis that selection against most but not all hybrid genotypes contributes to the observed genomic heterogeneity of introgression observed in adult trees. 
Experimental evidence for selection against hybrids was provided by the comparison of non-germinated but viable seeds and germinated seedlings from a hybrid zone between Q. rubra and Q. ellipsoidalis in a greenhouse common garden experiment [122]. Using genetic assignment analyses at microsatellite markers, Gailing and Zhang [122] characterized and compared the number of hybrids and "pure" species between non-germinated acorns and seedlings of two interfertile sympatric species, Q. rubra and Q. ellipsoidalis. Hybrids and introgressive forms in non-germinated acorns showed a frequency of $43.6 \%$ while they had a much lower frequency of $9.3 \%$ in the seedlings, indicating early selection against hybrids possibly as result of intrinsic incompatibilities between species [122]. However, direct evidence for environment dependent selection against hybrids is still missing.

\section{Distribution of Hybrids and Species Indicates Environmental Selection}

Curtu et al. $[80,98]$ found in a multi-species stand in central Romania that the white oak species $Q$. robur, Q. petraea, $Q$. pubescens, and $Q$. frainetto were distributed according to their soil preferences and environmental requirements, and that interspecific hybrids occurred in environmentally intermediate contact zones between species. This result is in accordance with several other findings in oaks $[46,70,77,86]$ and a long history of expectations about the effect of "hybridization of the habitat" on distribution of plant hybrids $[123,124]$. For example, Khodwekar \& Gailing [77] found that the distribution of species and hybrids was significantly associated with soil properties (i.e., soil water holding capacity, nutrient availability). Additionally, closely related oaks have been found to co-occur less frequently at the plot scale than distantly related oaks due to convergence on traits under strong environmental filtering $[84,125]$. The rapid evolution of fine-scale habitat differentiation seems, in fact, to be a hallmark of oak diversification [126] that contributes to the separation of potentially introgressing species both among and within forest stands.

These results suggest that pre-zygotic $[97,100,114]$ and post-zygotic $[98,122]$ isolation mechanisms play complementary roles in the maintenance of species identity in oaks. Findings of Gailing and Zhang [122] together with species distribution according to environmental requirements and observed lower hybrid frequencies in ancient hybrid zones $[127,128]$ serve as indirect evidence for selection as an important post-zygotic isolation mechanism in oaks. Experimentally disentangling pre-zygotic and post-zygotic isolation mechanisms might include (1) observations of the number of produced seeds and seedling survival derived from intra- and interspecific crosses, accompanied by (2) an assessment of hybrid survival in transplant experiments. Significantly lower hybrid survival as compared to "pure" species in each parental environment but higher survival in intermediate environments would indicate environmental selection (Figure 1). Alternatively, lower hybrid survival across all three environments would be indicative of selection against hybrids as result of intrinsic incompatibilities between species. While field studies are most appropriate for directly estimating selective effects, the axes of environmental variation affecting hybrid performance in intermediate and parental environments might be distinguished under controlled greenhouse conditions, for example with contrasting watering regimes. Whatever their form, experimental studies are an important next step toward a more nuanced understanding of the role of selection in oak species cohesion. 


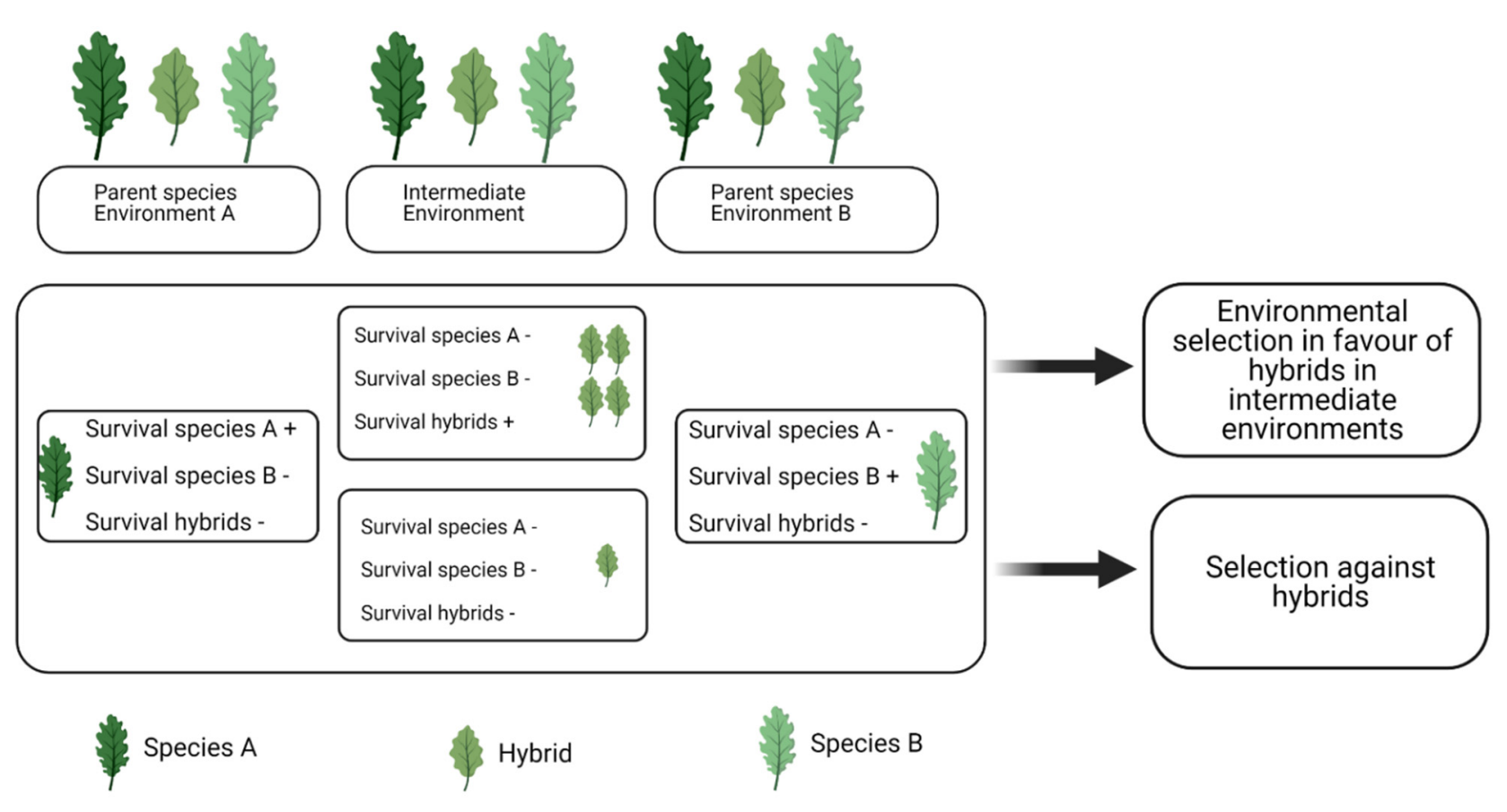

Figure 1. Outline of suggested transplant experiment. Hybrids and parental species are planted in each parental environment and in an intermediate environment. Environmental selection suggests the highest survival rate of parent species A and B in their respective environments. Two different scenarios may be expected for hybrids. Scenario 1: Hybrids show low survival in each parental environment, but higher survival in the intermediate environment, suggesting environmental selection in favor of hybrids in ecological transition zones. Scenario 2: Hybrids show low survival in each of the three environments, suggesting selection against hybrids. Created with BioRender.com, accessed on April 1st 2021.

\section{Adaptive Introgression}

The introgression of potentially adaptive alleles can have a large impact on adaptation to different environmental conditions. Evidence for adaptive introgression of outlier alleles was provided by the comparison of hybrid numbers and outlier allele frequencies in sympatric and parapatric populations of Q. rubra and Q. ellipsoidalis [77,129]. In neighbouring parapatric populations of the two species, genetic assignment analysis indicated symmetric interspecific gene flow, but introgression of Q. ellipsoidalis-specific alleles at a species-discriminating outlier locus (CONSTANS-like 1 ) into Q. rubra occurred at a lower rate than the introgression of Q. rubra-specific alleles into Q. ellipsoidalis [129]. Sympatric populations in dry outwash plains exhibited a similar discrepancy between symmetrical genome-scale introgression and asymmetrical outlier-locus introgression. However, outlier introgression from the drought adapted species Q. ellipsoidalis into Q. rubra was more prevalent in these dry outwash plains [77], concordant with the predictions of adaptive introgression [130]. Different directions of outlier alleles introgression in sympatric and parapatric populations suggests shifting selection regimes on these outliers in different spatial and environmental contexts. As these two species have different environmental preferences and outlier allele introgression seems to be related to environmental contrasts, the maintenance of genetic differences between these two species is likely dependent at least in part on environmental selection [77].

Clinal variation consistent with the geographic variation of introgression from $Q$. robur into $Q$. petraea displayed by some genes associated with phenological divergence in Q. petraea indicated adaptive introgression in outlier regions [44]. Quercus robur-like alleles, for example SNPs located in two important genes controlling stomatal responses, RopGEF1 and PBL10 (=APK1b) [131,132], were found with higher frequency in Q. petraea populations growing at higher altitudes in cooler and/or wetter environments, indicating that introgressed alleles from Q. robur serve as a source of phenotypic and potentially adaptive variation in Q. petraea [44]. These findings mirror and move beyond the find- 
ings of an earlier study that used range-wide genome scans of AFLPs in Californian red oaks [42] to show that the movement of introgressed loci beyond the natural range of their source species was predicted by climate, but without identifying the genes involved. With ongoing climate change, we may expect to find additional opportunities to study adaptive introgression. It is anticipated, for example, that Mediterranean oaks (Q. pyrenaica and $Q$. pubescens) will migrate north into the distribution area of temperate oak species (Q. petraea and Q. robur), providing a chance to study evolutionary processes in action at the present time [24]. Beginning these studies now may give us the opportunity to understand the roles of hybridization and adaptive introgression in climate change adaptation [47].

\section{Oak Reference Genome Sequences}

A full appreciation of all of the genetic components of variation underlying the capacity for adaptive divergence, speciation, reproductive isolation, and individual quantitative adaptive traits ultimately requires high-quality genome sequence assembly references [133]. Reference chromosome-scale genomes support investigations into variations in the coding sequence, chromosome structure at the macro (whole-genome) and micro (indel) levels, regulatory elements, non-coding RNAs, and positional effects (such as repetitive DNA environs). The approach initially available for assembling draft genome references was the de novo assembly of contigs and scaffolds, which for oak species included pedunculate oak, Q. robur (17,910 scaffolds) [53], and valley oak, Q. lobata (18,512 scaffolds) [54], both in the Quercus section of the genus and Q. suber (cork oak, (23,347 scaffolds) [41]) in the section Cerris. The $Q$. robur de novo assembly scaffolds were then anchored (ordered) by reference to a high-density genetic linkage map [134], providing chromosome-scale sequences for $Q$. robur covering $96 \%(716.6 \mathrm{Mb})$ of the haploid genome size [38]. The contiguous chromosome-scale genome for $Q$. robur contains $90 \%$ of the consensus set of 25,808 annotated protein-coding genes predicted in the de novo genome. Certain features of oak genomes, discovered from the chromosome-scale genome assembly of $Q$. robur, may impact studies on hybridization, introgression, and adaptation, including a high level $(35.6 \%)$ of proximal tandem duplications of genes and inheritance of somatic mutations arising during the long lifespan of oak trees [38]. The extent to which tandem duplication of genes is consistent across the genus, or specific to lineages within oaks, will require chromosome-scale genome assemblies for representatives of the other sections of the oak genus. Recent technology advancements for enabling chromosome-scale genome assemblies, such as Hi-C and nanopore, are now widely in use. A contiguous chromosomescale genome assembly for northern red oak (Q. rubra), in the Quercus section Lobatae, has recently been completed and will soon be released on the Joint Genome Institute's Phytozome 13 (https: / / phytozome-next.jgi.doe.gov/, accessed on 28 April 2021). The northern red oak genome, and anticipated additional chromosome-scale oak genomes for oaks, will enable detailed comparative studies at the whole-genome level on pan-genome organization, phylogeny, maintenance of species integrity, hybridization, and adaptations among oaks genus-wide.

\section{Genomic Distribution and Architecture of Differentiation}

As already pointed out, selection may direct interspecific gene flow between sympatric oak species. However, outliers exist because effective gene flow is in at least some loci reduced, potentially accelerating the accumulation of alleles involved in reproductive isolation [21]. Genome scans in both European white oaks (section Quercus in part) and North American red oaks (section Lobatae), each of which is composed of ecologically divergent but interfertile oak species, have revealed strong divergent selection on only a few so-called outlier loci $[14,44,79,135,136]$. Outlier loci exhibit high allele-frequency divergence and are presumed in many cases to be affected by selection in the genomic region in which they occur, due either to direct selection or selection on closely linked loci. They are referred to as "outliers" because they exhibit differentiation that deviates significantly from neutral expectations [136]. Methods that are widely used to detect these 
loci are $\mathrm{F}_{\mathrm{ST}}$-based neutrality tests, where the $\mathrm{F}_{\mathrm{ST}}$ values of individual loci are tested against a simulated null distribution that is derived from a neutral island model of migration [137]. Another method widely used is the Bayesian method as implemented in BAYESCAN [138]. Alternative methods use environmental variables for outlier detection, implemented in software such as BAYENV2 [139] and BAYESCENV [140]. There are some constraints of $\mathrm{F}_{\mathrm{ST}}$ outlier detection methods that should be considered, such as number of sampled demes [141] and population structure [142], and it does not display absolute differentiation, but differentiation relative to the total variation (see [143]). The menagerie of genomic tests for selection is the subject of a specialized literature (e.g., [144-146]) that is well beyond the scope of our review. In concert, these methods comprise a suite of tools, in some cases complementary, in others redundant. Overall, however, these methods are crucial to answering a question central to understanding the genomic architecture of differentiation and adaptive introgression in oaks and other species: which loci are exchanged between species, which are not, and under what spatial and environmental conditions does differentiation give way to introgression? Once identified, divergent loci can be localized in the genome using high resolution genetic linkage maps anchored to scaffolds of sequenced genomes $[33,89,134]$.

Outlier loci have been identified for different oak species with contrasting ecological preferences, few of them showing very high interspecific differentiation as evidence for strong divergent selection. For example, one $\mathrm{F}_{\text {ST }}$ outlier (FIR013, an EST-SSR [147]) was identified when screening four Q. rubra/Q. ellipsoidalis species pairs from three different geographic regions using nuclear microsatellite markers and expressed sequence tag ESTSSR markers [82,136]. FIR013 was detected as an outlier in all geographic regions and pairwise comparisons, and was almost fixed for alternative alleles in the two species with values of interspecific $\mathrm{F}_{\mathrm{ST}}$ ranging from $55 \%$ to $80 \%$. The EST from which FIR013 was developed was annotated as CONSTANS-like (COL) gene, a candidate gene for flowering time and growth cessation in late summer [148]. CONSTANS-like genes are also involved in growth/development and phenology in other species [149,150], and it is thus possible that this gene may play a role in adaptive divergence between species through both ecological and phenological divergence [136]. Another outlier identified between $Q$. rubra and Q. ellipsoidalis included a histidine kinase 4-like gene (marker GOT021) [81], which was also detected as an outlier between Q. pyrenaica and Q. faginea [14]. Histidine kinase is shown to be an important part of a signaling cascade to effect stomatal closure in response to environmental and endogenous stimuli in Arabidopsis [151]. Additionally, GOT021 underlay a QTL for leaf shape variation in a Q. robur full-sib family [152]. The fact that it is an $\mathrm{F}_{\mathrm{ST}}$ outlier in different sections suggests that this marker may be involved in the maintenance of species integrity across a broad phylogenetic range of oaks as a result of parallel environmental selection. The genomic architecture of such loci associated with species differentiation may be non-random and under parallel divergence pressure across the genus. A study of genomic coherence in eight species of the eastern North American white oak syngameon, for example, found SNPs that are fixed or nearly fixed across species' ranges [75]. SNPs divergent between species map back to all 12 Quercus linkage groups (chromosomes) and are separated from each other by an average of 7.47 million bp. The proportion of divergent SNPs separated by $<10,000 \mathrm{bp}$ is significantly higher than the null distribution, suggesting that genome-wide patterns of divergence may be concentrated on chromosomes or in regions of the genome that reflect a higher-than-average history of among-species divergence.

An outlier screen using genomic SSR markers widely distributed across the genome was performed in European white oaks as well $[14,79,135]$. Scotti-Saintagne et al. [79] recorded a potential hotspot of interspecific differentiation between $Q$. robur and Q. petraea on linkage group 12 (LG12). Goicoechea et al. [14] included related Mediterranean species, Q. pyrenaica and Q. faginea, in the analysis. Two genomic SSRs, QrZag87 (located on LG2) and QrZag112 (LG12), were identified as outliers in Q. pyrenaica/Q. faginea [14], as well as in Q. robur/Q. petraea [135]. 
Leroy et al. [44] performed genome-wide scans in Q. petraea populations sampled along latitudinal and elevational gradients to study local adaptation. Additionally, reference populations of other European white oak species were included ( $Q$. robur, Q. pubescens and Q. pyrenaica) [47] to detect outliers potentially discovering footprints of divergence between these populations. To identify SNPs potentially subjected to selection within Q. petraea, $\mathrm{Xt}$ X statistics (analogous to $\mathrm{F}_{\mathrm{ST}}$ but specifically corrected for covariance matrix of allele frequency between populations, accounting for neutral correlations of allelic frequencies [139]) were calculated. 761,554 SNPs deviating from neutral expectations distributed over all chromosomes were detected, which is $2.05 \%$ of all investigated SNPs. Outliers were strongly enriched in SNPs which differentiated Q. robur from Q. petraea: strong correlations between intraspecific $\mathrm{XtX}$ values in 18 Q. petraea populations and interspecific $F_{\mathrm{ST}}$ between $Q$. robur and Q. petraea suggested that these SNPs are potentially under diversifying selection within and among species. Among the SNPs detected in Q. petraea association studies between genotype and environment/phenotype, 1331 SNPs were associated with temperature, 2932 with precipitation, and 1572 with leaf unfolding. The largest proportion of SNPs was significantly associated with both temperature and leaf unfolding, and those were highly enriched in SNPs strongly differentiated between $Q$. robur and Q. petraea. Subsequently, 167 unique candidate genes involved in different growth and developmental processes such as stomatal responses to water stress (e.g., $A L Y 4$, ALMT9, PBL10, PP2AA, RopGEF1, SUS3, SCD1) and some temperature associated genes acting as regulators of production of gibberellins were identified (e.g., GAMT2, ASPG1 or GA20x) [44].

In a companion paper, Leroy et al. [47] searched for candidate genes in regions enriched in outliers in the same four European white oak species based on a large data set of 31 million SNPs. In total, 227 genes were identified, from which at least 32 genes were assigned to three major functional categories (genes underlying ecological preferences of the four species, genes involved in biotic interactions, and those involved in intrinsic barriers (for the list of genes see Table 2 in [47])). Among these 32 genes, 6 candidate genes were detected as outliers for all species pairs. Four of these genes are putatively involved in intrinsic barriers, two are involved in pollen development (Cycloartenol synthase 2), and two in photoreceptor and UV-B tolerance. One of these-UVR8-was also detected as a gene under positive selection in Juglans siligata [153]. The other two outliers have a putative role in ecological barriers (regulator of root growth and role in soil-water deficit stress). Four outlier candidate genes related to drought tolerance were present in all observed species pairs except $Q$. robur-Q. petraea [47], which is consistent with the higher drought tolerance of $Q$. pubescens and Q. pyrenaica than in these two species [154]. One of the genes$V R N 1$, detected in all species pairs except in Q. robur-Q. petraea-plays a role in acclimation to low temperatures, and has been identified as a candidate gene for cold tolerance in many other plant species [155]. In general, most outlier SNPs contributing to reproductive barriers differentiate southern from northern species, suggesting that these barriers are driven by climate preferences [47]. Another association study on Q. robur, Q. petraea, and Q. pubescens was conducted by Rellstab et al. [156], who identified common patterns of SNP-environment associations across species for seven genes among 95 targeted genes, suggesting a role in local adaptation [156]. Genes gigantea and galactinol synthase (GolS1) from this study were also detected by Alberto et al. [157] as candidate genes for bud burst in Q. petraea. Additional genes showing patterns of local adaptation across different oak and related species of the beech family can be found in a recent review [158].

Whole genome outlier screens across species pairs can be used in combination with association analysis within species sampled across environmental gradients (Figure 2) to detect genes involved in both local adaptation within species and adaptive divergence between species. Such outliers, present in both analyses, are candidate genes for adaptive divergence and reproductive isolation between species [44,159]. Association analyses of genetic variation (single nucleotide polymorphisms, SNPs) with adaptive trait variation can be performed in segregating populations using QTL mapping approaches to detect 
associated genomic regions $[79,134,160]$. To narrow down these regions to individual genes, association mapping in unstructured populations such as provenance trials is required [133]. Additionally, environmental association analyses between SNP variation and environmental variables can be used to identify adaptive genetic variation $[44,65,157,161]$. Moreover, populations in extreme environments of the environmental cline can be selected for outlier analyses [33].

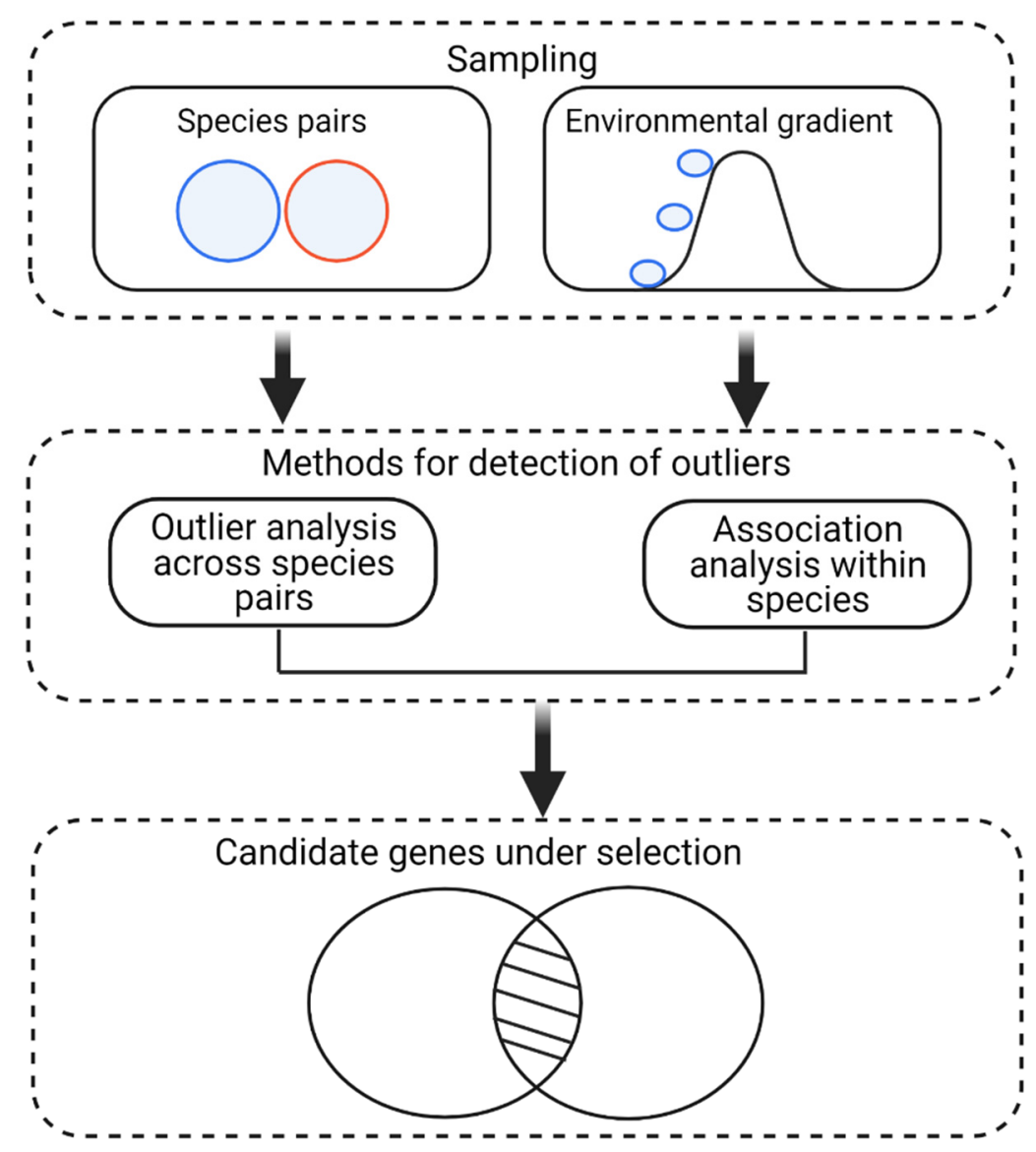

Figure 2. Workflow of detecting candidate genes under selection involved in adaptive divergence within and between species. Steps are explained in detail in the manuscript. Created with BioRender. com, accessed on 1 April 2021.

A final approach that has been illuminating in understanding the genomic architecture of differentiation in oaks is mapping phylogenetically informative loci back to the genome to determine whether (1) loci that recover introgression history are genomically clustered, following population-level studies of species divergence (e.g., [79]); or (2) loci that track divergence are replicated in different clades. Several studies have utilized phylogenomic datasets to explicitly model divergent vs. introgressive histories in oaks [69,90,99,162-167]. Two studies have then mapped loci implicated in ancient introgression vs. divergence in the white oaks (Quercus section Quercus) back to the genome to characterize the genomic distribution of divergence history $[49,163]$. Both studies failed to find that introgressive loci were clustered on the genome, presumably because the long history of recombination has eroded linkage disequilibrium connecting loci in ancient introgression events. Moreover, one of the studies [49] demonstrated that the loci recovering the divergence history in lieu of the dominant introgression history for alternative regions of the white phylogeny are also not related to one another. Thus, they reject the hypothesis that there are particular genes or regions of the genome that define the oak phylogeny globally. The evolutionary history of oaks is a mosaic history. 


\section{Conclusions and Future Perspectives}

As summarized above, many studies have dealt with hybridization in oaks, but the decreasing costs and flexibility of whole genome sequencing and reduced representation genomic sequencing make it possible to study the evolutionary implications of hybridization and introgression at much higher genomic and spatial resolutions today [24]. To better understand the genetic basis for the maintenance of species integrity in oaks in the face of interspecific gene flow and the roles of genes that distinguish species, additional studies observing outlier regions between sympatric oak species should be performed. Analyzing oaks with different adaptations, for example to drought, might reveal whether there is a higher number of genes associated with adaptive divergence for drought tolerance and reproductive isolation between the ecologically divergent oak species in outlier genomic regions than in shared regions. Comparison of outlier genes identified between species with different environmental requirements across different sections can reveal genomic divergence unique to oak sections, or parallel genomic divergence driven by natural selection. Such outlier genes or regions detected across sections are prime candidates for adaptive species divergence by environmental selection. Whole genome resequencing can be used for the detection of such outliers and in combination with environmental association analysis, genome wide association studies (GWAS), and QTL mapping, candidate genes for speciation processes involved in adaptive divergence within and between species can be identified.

The focus of this review is solely on oaks and their maintenance of species integrity despite ongoing gene flow, hybridization, and introgression. Oaks, however, have the potential to illuminate speciation patterns in complement with immensely different speciation models such as sunflowers [168] and irises [169], where hybridization is a major driver of speciation. By contrast with the other models, in which hybridization triggers speciation [170], oaks exhibit a facilitation of adaptation via hybridization [44,48,69]. Equally important, hybridization appears not to threaten species integrity in oaks, even though a limited part of the genome-potentially a very limited portion, composed of only small regions distributed across the genome-is responsible for maintaining species barriers [24]. Thus, oaks are an alternative model of species differentiation, maintenance, and conservation that are equally important to understanding the tangled ways of speciation.

Author Contributions: Conceptualization, O.G., A.L.H., and J.E.C.; writing-original draft preparation, D.L.; writing-review and editing, O.G., A.L.H., J.E.C., and D.L.; supervision, O.G.; project administration, O.G.; funding acquisition, O.G. All authors have read and agreed to the published version of the manuscript.

Funding: This research was funded by Deutsche Forschungsgemeinschaft (DFG, German Research Foundation, Reference number: 429696097 (GA 714/7-1)).

Acknowledgments: We thank Katharina Birgit Budde for her support and constructive discussions.

Conflicts of Interest: The authors declare no conflict of interest. The funders had no role in the design of the study, the writing of the manuscript, or the decision to publish the results.

\section{References}

1. Darwin, C. On the Origin of Species by Means of Natural Selection, or the Preservation of Favoured Races in the Struggle for Life; John Murray: London, UK, 1859.

2. Schluter, D. Evidence for ecological speciation and its alternative. Science 2009, 323, 737-741. [CrossRef]

3. Via, S. Natural selection in action during speciation. Proc. Natl. Acad. Sci. USA 2009, 106, 9939-9946. [CrossRef] [PubMed]

4. Richards, E.J.; Servedio, M.R.; Martin, C.H. Searching for sympatric speciation in the genomic era. BioEssays 2019, 41. [CrossRef]

5. Matute, D.R.; Cooper, B.S. Comparative studies on speciation: 30 years since Coyne and Orr. Evolution 2021, 75, 764-778. [CrossRef] [PubMed]

6. Nosil, P.; Feder, J.L.; Gompert, Z. How many genetic changes create new species? Science 2021, 371, 777-780. [CrossRef] [PubMed]

7. Nosil, P. Ecological Speciation; Oxford University Press: Oxford, UK, 2012.

8. Nosil, P.; Feder, J.L. Genomic divergence during speciation: Causes and consequences. Philos. Trans. R. Soc. B Biol. Sci. 2012, 367, 332-342. [CrossRef] 
9. Rundle, H.D.; Nosil, P. Ecological speciation. Ecol. Lett. 2005, 8, 336-352. [CrossRef]

10. Schluter, D. Ecology and the origin of species. Trends Ecol. Evol. 2001, 16, 372-380. [CrossRef]

11. Mayr, E. Systematics and the Origin of Species; Columbia University Press: New York, NY, USA, 1942.

12. Dobzhansky, T. Genetics and the Origin of Species; Columbia University Press: New York, NY, USA, 1937.

13. Coyne, J.A.; Orr, H.A. Speciation; Sinauer: Sunderland, MA, USA, 2004.

14. Goicoechea, P.G.; Herrán, A.; Durand, J.; Bodénès, C.; Plomion, C.; Kremer, A. A linkage disequilibrium perspective on the genetic mosaic of speciation in two hybridizing Mediterranean white oaks. Heredity 2015, 114, 373-386. [CrossRef]

15. Nosil, P.; Funk, D.J.; Ortiz-Barrientos, D. Divergent selection and heterogeneous genomic divergence. Mol. Ecol. 2009, 18, 375-402. [CrossRef]

16. Oleksyk, T.K.; Smith, M.W.; O’Brien, S.J. Genome-wide scans for footprints of natural selection. Philos. Trans. R. Soc. B Biol. Sci. 2010, 365, 185-205. [CrossRef]

17. Via, S.; West, J. The genetic mosaic suggests a new role for hitchhiking in ecological speciation. Mol. Ecol. 2008, 17, 4334-4345. [CrossRef]

18. Harr, B. Genomic islands of differentiation between house mouse subspecies. Genome Res. 2006, 16, 730-737. [CrossRef]

19. Yatabe, Y.; Kane, N.C.; Scotti-Saintagne, C.; Rieseberg, L.H. Rampant gene exchange across a strong reproductive barrier between the annual sunflowers, Helianthus annuus and H. petiolaris. Genetics 2007, 175, 1883-1893. [CrossRef] [PubMed]

20. Turner, T.L.; Hahn, M.W.; Nuzhdin, S.V. Genomic islands of speciation in Anopheles gambiae. PLoS Biol. 2005, 3, 1572-1578. [CrossRef]

21. Via, S. Divergence hitchhiking and the spread of genomic isolation during ecological speciation-with-gene-flow. Philos. Trans. $R$. Soc. B Biol. Sci. 2012, 367, 451-460. [CrossRef] [PubMed]

22. Brady, K.U.; Kruckeberg, A.R.; Bradshaw, H.D. Evolutionary ecology of plant adaptation to serpentine soils. Annu. Rev. Ecol. Evol. Syst. 2005, 36, 243-266. [CrossRef]

23. Lexer, C.; Lai, Z.; Rieseberg, L.H. Candidate gene polymorphisms associated with salt tolerance in wild sunflower hybrids: Implications for the origin of Helianthus paradoxus, a diploid hybrid species. New Phytol. 2004, 161, 225-233. [CrossRef]

24. Kremer, A.; Hipp, A.L. Oaks: An evolutionary success story. New Phytol. 2020, 226, 987-1011. [CrossRef]

25. Raeymaekers, J.A.M.; Chaturvedi, A.; Hablützel, P.I.; Verdonck, I.; Hellemans, B.; Maes, G.E.; De Meester, L.; Volckaert, F.A.M. Adaptive and non-adaptive divergence in a common landscape. Nat. Commun. 2017, 8, 1-8. [CrossRef] [PubMed]

26. Ågren, J.; Oakley, C.G.; Lundemo, S.; Schemske, D.W. Adaptive divergence in flowering time among natural populations of Arabidopsis thaliana: Estimates of selection and QTL mapping. Evolution 2017, 71, 550-564. [CrossRef]

27. Orr, H.A.; Masly, J.P.; Presgraves, D.C. Speciation genes. Curr. Opin. Genet. Dev. 2004, 14, 675-679. [CrossRef]

28. Wu, C.I.; Ting, C.T. Genes and speciation. Nat. Rev. Genet. 2004, 5, 114-122. [CrossRef] [PubMed]

29. Rieseberg, L.H.; Blackman, B.K. Speciation genes in plants. Ann. Bot. 2010, 106, 439-455. [CrossRef]

30. Nosil, P.; Schluter, D. The genes underlying the process of speciation. Trends Ecol. Evol. 2011, 26, 160-167. [CrossRef] [PubMed]

31. Leroy, T.; Plomion, C.; Kremer, A. Oak symbolism in the light of genomics. New Phytol. 2020, 226, 1012-1017. [CrossRef] [PubMed]

32. Neale, D.B.; Kremer, A. Forest tree genomics: Growing resources and applications. Nat. Rev. Genet. 2011, 12, 111-122. [CrossRef] [PubMed]

33. González-Martínez, S.C.; Krutovsky, K.V.; Neale, D.B. Forest-tree population genomics and adaptive evolution. New Phytol. 2006, 170, 227-238. [CrossRef] [PubMed]

34. Holliday, J.A.; Aitken, S.N.; Cooke, J.E.K.; Fady, B.; González-Martínez, S.C.; Heuertz, M.; Jaramillo-Correa, J.-P.; Lexer, C.; Staton, M.; Whetten, R.W.; et al. Advances in ecological genomics in forest trees and applications to genetic resources conservation and breeding. Mol. Ecol. 2017, 26, 706-717. [CrossRef]

35. Plomion, C.; Bastien, C.; Bogeat-Triboulot, M.B.; Bouffier, L.; Déjardin, A.; Duplessis, S.; Fady, B.; Heuertz, M.; Le Gac, A.L.; Le Provost, G.; et al. Forest tree genomics: 10 achievements from the past 10 years and future prospects. Ann. For. Sci. 2016, 73, 77-103. [CrossRef]

36. Tuscan, A.; DiFazio, S.; Jansson, S.; Putnam, N.; Ralph, S.; Rombauts, S.; Salamov, A.; Schein, J.; Sterck, L.; Aerts, A. The Genome of Black Cottonwood, Populus trichocarpa (Torr. \& Gray). Science 2006, 313, 1596-1604.

37. Myburg, A.A.; Grattapaglia, D.; Tuskan, G.A.; Hellsten, U.; Hayes, R.D.; Grimwood, J.; Jenkins, J.; Lindquist, E.; Tice, H.; Bauer, D.; et al. The genome of Eucalyptus grandis. Nature 2014, 510, 356-362. [CrossRef]

38. Plomion, C.; Aury, J.M.; Amselem, J.; Leroy, T.; Murat, F.; Duplessis, S.; Faye, S.; Francillonne, N.; Labadie, K.; Le Provost, G.; et al. Oak genome reveals facets of long lifespan. Nat. Plants 2018, 4, 440-452. [CrossRef]

39. Nystedt, B.; Street, N.R.; Wetterbom, A.; Zuccolo, A.; Lin, Y.C.; Scofield, D.G.; Vezzi, F.; Delhomme, N.; Giacomello, S.; Alexeyenko, A.; et al. The Norway spruce genome sequence and conifer genome evolution. Nature 2013, 497, 579-584. [CrossRef]

40. Sork, V.L.; Fitz-Gibbon, S.T.; Puiu, D.; Crepeau, M.; Gugger, P.F.; Sherman, R.; Stevens, K.; Langley, C.H.; Pellegrini, M.; Salzberg, S.L. First draft assembly and annotation of the genome of a California endemic oak Quercus lobata Née (Fagaceae). G3 Genes Genomes Genet. 2016, 6, 3485-3495.

41. Ramos, A.M.; Usié, A.; Barbosa, P.; Barros, P.M.; Capote, T.; Chaves, I.; Simões, F.; Abreu, I.; Carrasquinho, I.; Faro, C.; et al. The draft genome sequence of cork oak. Sci. Data 2018, 5, 180069. [CrossRef] [PubMed]

42. Dodd, R.S.; Afzal-Rafii, Z. Selection and dispersal in a multispecies oak hybrid zone. Soc. Study Evol. 2004, 58, 261-269. 
43. Howard, D.J.; Preszler, R.W.; Williams, J.; Fenchel, S.; Boecklen, W.J. How discrete are oak species? Insights from a hybrid zone between Quercus grisea and Quercus gambelii. Evolution 1997, 51, 747-755. [CrossRef]

44. Leroy, T.; Louvet, J.M.; Lalanne, C.; Le Provost, G.; Labadie, K.; Aury, J.M.; Delzon, S.; Plomion, C.; Kremer, A. Adaptive introgression as a driver of local adaptation to climate in European white oaks. New Phytol. 2020, 226, 1171-1182. [CrossRef]

45. Maze, J. Past Hybridization between Quercus macrocarpa and Quercus gambelii. Brittonia 1968, 20, 321-333. [CrossRef]

46. Muller, H.C. Ecological control of hybridization in Quercus: A factor in the mechanism of evolution. Evolution 1952, 6, 147-161.

47. Leroy, T.; Rougemont, Q.; Dupouey, J.L.; Bodénès, C.; Lalanne, C.; Belser, C.; Labadie, K.; Le Provost, G.; Aury, J.M.; Kremer, A.; et al. Massive postglacial gene flow between European white oaks uncovered genes underlying species barriers. New Phytol. 2019. [CrossRef]

48. Leroy, T.; Roux, C.; Villate, L.; Bodénès, C.; Romiguier, J.; Paiva, J.A.P.; Dossat, C.; Aury, J.M.; Plomion, C.; Kremer, A. Extensive recent secondary contacts between four European white oak species. New Phytol. 2017, 214, 865-878. [CrossRef] [PubMed]

49. Hipp, A.L.; Manos, P.S.; Hahn, M.; Avishai, M.; Bodénès, C.; Cavender-Bares, J.; Crowl, A.A.; Deng, M.; Denk, T.; Fitz-Gibbon, S.; et al. Genomic landscape of the global oak phylogeny. New Phytol. 2020, 226, 1198-1212. [CrossRef] [PubMed]

50. Hubert, F.; Grimm, G.W.; Jousselin, E.; Berry, V.; Franc, A.; Kremer, A. Multiple nuclear genes stabilize the phylogenetic backbone of the genus Quercus. Syst. Biodivers. 2014, 12, 405-423. [CrossRef]

51. Manos, P.S.; Stanford, A.M. The historical biogeography of Fagaceae: Tracking the tertiary history of temperate and subtropical forests of the northern hemisphere. Int. J. Plant Sci. 2012, 162, S77-S93. [CrossRef]

52. Denk, T.; Grimm, G.W.; Manos, P.S.; Deng, M.; Hipp, A. An updated infrageneric classification of the oaks: Review of previous taxonomic schemes and synthesis of evolutionary patterns. In Oaks Physiological Ecology. Exploring the Functional Diversity of Genus Quercus L.; Springer International Publishing: New York, NY, USA, 2017; pp. 13-38.

53. Plomion, C.; Aury, J.M.; Amselem, J.; Alaeitabar, T.; Barbe, V.; Belser, C.; Berges, H.; Bodénès, C.; Boudet, N.; Boury, C.; et al. Decoding the oak genome: Public release of sequence data, assembly, annotation and publication strategies. Mol. Ecol. Resour. 2016, 16, 254-265. [CrossRef]

54. Sork, V.L.; Squire, K.; Gugger, P.F.; Steele, S.E.; Levy, E.D.; Eckert, A.J. Landscape genomic analysis of candidate genes for climate adaptation in a California endemic oak, Quercus lobata. Am. J. Bot. 2016, 103, 33-46. [CrossRef]

55. Aldrich, P.; Cavender-Bares, J. Quercus. In Wild Crop Relatives: Genomic and Breeding Resources, Forest Trees; Springer: Berlin, Germany, 2011; pp. 89-129.

56. Bar-Yosef, O.; Belfer-Cohen, A. Following Pleistocene road signs of human dispersals across Eurasia. Quat. Int. 2013, 285, 30-43. [CrossRef]

57. Cavender-Bares, J. Diversity, distribution and ecosystem services of the North American oaks. Int. Oaks 2016, 27, 37-48.

58. Chadwick, H.M. The Oak and the Thunder-God. J. Anthropol. Inst. G. B. Irel. 1900, 30, 22-44. [CrossRef]

59. Chassé, B. Eating Acorns: What Story Do the Distant, Far, and Near Past Tell Us, and Why? Int. Oaks 2016, 107-135.

60. Logan, W.B. Oak: The Frame of Civilization; W.W. Norton \& Company, Inc.: New York, NY, USA, 2005.

61. Thirgood, J. The historical significance of oak. In Proceedings of the Oak Symposium; U.S. Department of Agriculture, Forest Service, Northeastern Forest Experiment Station: Upper Darby, PA, USA; Morgantown, WV, USA, 1971.

62. Lev, E.; Kislev, M.E.; Bar-Yosef, O. Mousterian vegetal food in Kebara Cave, Mt. Carmel. J. Archaeol. Sci. 2004, 475-484. [CrossRef]

63. Schmid-Siegert, E.; Sarkar, N.; Iseli, C.; Calderon, S.; Gouhier-Darimont, C.; Chrast, J.; Cattaneo, P.; Schütz, F.; Farinelli, L.; Pagni, M.; et al. Low number of fixed somatic mutations in a long-lived oak tree. Nat. Plants 2017, 3, 926-929. [CrossRef]

64. Rieseberg, L.H.; Wood, T.E.; Baack, E.J. The nature of plant species. Nature 2006, 440, 524-527. [CrossRef]

65. Reutimann, O.; Gugerli, F.; Rellstab, C. A species-discriminatory single-nucleotide polymorphism set reveals maintenance of species integrity in hybridizing European white oaks (Quercus spp.) despite high levels of admixture. Ann. Bot. 2020, 125, 663-676. [CrossRef]

66. Hipp, A.L.; Weber, J.A. Taxonomy of Hill's oak (Quercus ellipsoidalis: Fagaceae): Evidence from AFLP data. Syst. Bot. 2008, 33, 148-158. [CrossRef]

67. González-Rodríguez, A.; Oyama, K. Leaf morphometric variation in Quercus affinis and Q. laurina (Fagaceae), two hybridizing Mexican red oaks. Bot. J. Linn. Soc. 2005, 147, 427-435. [CrossRef]

68. González-Rodríguez, A.; Arias, D.M.; Valencia, S.; Oyama, K. Morphological and RAPD analysis of hybridization between Quercus affinis and Q. laurina (Fagaceae), two Mexican red oaks. Am. J. Bot. 2004, 91, 401-409. [CrossRef]

69. Eaton, D.A.R.; Hipp, A.L.; González-Rodríguez, A.; Cavender-Bares, J. Historical introgression among the American live oaks and the comparative nature of tests for introgression. Evolution 2015, 69, 2587-2601. [CrossRef] [PubMed]

70. Moran, E.V.; Willis, J.; Clark, J.S. Genetic evidence for hybridization in red oaks (Quercus sect. Lobatae, Fagaceae). Am. J. Bot. 2012, 99, 92-100. [CrossRef]

71. Van Valen, L. Ecological species, multispecies, and oaks. Taxon 1976, 25, 233-239. [CrossRef]

72. Burger, W.C. The species concept in Quercus. Taxon 1975, 24, 45-50. [CrossRef]

73. Cannon, C.H.; Petit, R.J. The oak syngameon: More than the sum of its parts. New Phytol. 2020, 226, 978-983. [CrossRef] [PubMed]

74. Cronk, Q.C.; Suarez-Gonzalez, A. The role of interspecific hybridization in adaptive potential at range margins. Mol. Ecol. 2018, 27, 4653-4656. [CrossRef] [PubMed] 
75. Hipp, A.L.; Whittemore, A.T.; Garner, M.; Hahn, M.; Fitzek, E.; Guichoux, E.; Cavender-Bares, J.; Gugger, P.F.; Manos, P.S.; Pearse, I.S.; et al. Genomic identity of white oak species in an Eastern North American Syngameon. Ann. Mo. Bot. Gard. 2019, 104, 455-477. [CrossRef]

76. Lotsy, J. Species or Linneon. Genetica 1925, 7, 487-506. [CrossRef]

77. Khodwekar, S.; Gailing, O. Evidence for environment-dependent introgression of adaptive genes between two red oak species with different drought adaptations. Am. J. Bot. 2017, 104, 1088-1098. [CrossRef]

78. Sullivan, A.R.; Owusu, S.A.; Weber, J.A.; Hipp, A.L.; Gailing, O. Hybridization and divergence in multi-species oak (Quercus) communities. Bot. J. Linn. Soc. 2016, 181, 99-114. [CrossRef]

79. Scotti-Saintagne, C.; Mariette, S.; Porth, I.; Goicoechea, P.G.; Barreneche, T.; Bodénès, C.; Burg, K.; Kremer, A. Genome scanning for interspecific differentiation between two closely related oak species [Quercus robur L. and Q. petraea (Matt.) Liebl]. Genetics 2004, 168, 1615-1626. [CrossRef]

80. Curtu, A.L.; Gailing, O.; Finkeldey, R. Evidence for hybridization and introgression within a species-rich oak (Quercus spp.) community. BMC Evol. Biol. 2007, 7, 218. [CrossRef] [PubMed]

81. Lind, J.F.; Gailing, O. Genetic structure of Quercus rubra L. and Quercus ellipsoidalis E. J. Hill populations at gene-based EST-SSR and nuclear SSR markers. Tree Genet. Genomes 2013, 9, 707-722. [CrossRef]

82. Collins, E.; Sullivan, A.R.; Gailing, O. Limited effective gene flow between two interfertile red oak species. Trees Struct. Funct. 2015, 29, 1135-1148. [CrossRef]

83. Owusu, S.A.; Sullivan, A.R.; Weber, J.A.; Hipp, A.L.; Gailing, O. Taxonomic relationships and gene flow in four North American Quercus species (Quercus section Lobatae). Syst. Bot. 2015, 40, 510-521. [CrossRef]

84. Cavender-Bares, J.; Ackerly, D.D.; Baum, D.A.; Bazzaz, F.A. Phylogenetic overdispersion in Floridian oak communities. Am. Nat. 2004, 163, 823-843. [CrossRef]

85. Gailing, O. Differences in growth, survival and phenology in Quercus rubra and Q. ellipsoidalis seedlings. Dendrobiology 2013, 70, 73-81. [CrossRef]

86. López De Heredia, U.; Valbuena-Carabaña, M.; Córdoba, M.; Gil, L. Variation components in leaf morphology of recruits of two hybridising oaks [Q. petraea (Matt.) Liebl. and Q. pyrenaica Willd.] at small spatial scale. Eur. J. For. Res. 2009, 128, 543-554. [CrossRef]

87. Valbuena-Carabaña, M.; González-Martínez, S.C.; Sork, V.L.; Collada, C.; Soto, A.; Goicoechea, P.G.; Gil, L. Gene flow and hybridisation in a mixed oak forest (Quercus pyrenaica Willd. and Quercus petraea (Matts.) Liebl.) in central Spain. Heredity 2005, 95, 457-465. [CrossRef]

88. Cottam, W.; Tucker, J.; Santamour, F. Oak Hybridization at the University of Utah; State Arboretum of Utah: Salt Lake City, UT, USA, 1982.

89. Gailing, O.; Curtu, A.L. Interspecific gene flow and maintenance of species integrity in oaks. Ann. For. Res. 2014, 57, 5-18. [CrossRef]

90. McVay, J.D.; Hipp, A.L.; Manos, P.S. A genetic legacy of introgression confounds phylogeny and biogeography in oaks. Proc. R. Soc. B Biol. Sci. 2017, 284, 20170300. [CrossRef]

91. Manos, P.S.; Doyle, J.J.; Nixon, K.C. Phylogeny, biogeography, and processes of molecular differentiation in Quercus subgenus Quercus (Fagaceae). Mol. Phylogenet. Evol. 1999, 12, 333-349. [CrossRef]

92. Pham, K.K.; Hipp, A.L.; Manos, P.S.; Cronn, R.C. A time and a place for everything: Phylogenetic history and geography as joint predictors of oak plastome phylogeny. Genome 2017, 60, 720-732. [CrossRef]

93. Abrams, M.D. Comparative water relations of three successional hardwood species in central Wisconsin. Tree Physiol. 1988, 4, 263-273. [CrossRef] [PubMed]

94. Abrams, M.D. Adaptations and responses to drought in Quercus species of North America. Tree Physiol. 1990, 7, 227-238. [CrossRef] [PubMed]

95. Bréda, N.; Cochard, H.; Dreyer, E.; Granier, A. Field comparison of transpiration, stomatal conductance and vulnerability to cavitation of Quercus petraea and Quercus robur under water stress. Ann. des Sci. For. 1993, 50, 571-582. [CrossRef]

96. Cavender-Bares, J.; Pahlich, A. Molecular, morphological, and ecological niche differentiation of sympatric sister oak species, Quercus virginiana and Q. geminata (Fagaceae). Am. J. Bot. 2009, 96, 1690-1702. [CrossRef] [PubMed]

97. Petit, R.J.; Bodénès, C.; Ducousso, A.; Roussel, G.; Kremer, A. Hybridization as a mechanism of invasion in oaks. New Phytol. 2003, 161, 151-164. [CrossRef]

98. Curtu, A.L.; Gailing, O.; Finkeldey, R. Patterns of contemporary hybridization inferred from paternity analysis in a four-oakspecies forest. BMC Evol. Biol. 2009, 9, 284. [CrossRef]

99. McVay, J.D.; Hauser, D.; Hipp, A.L.; Manos, P.S. Phylogenomics reveals a complex evolutionary history of lobed-leaf white oaks in western North America. Genome 2017, 60, 733-742. [CrossRef]

100. Lepais, O.; Petit, R.J.; Guichoux, E.; Lavabre, J.E.; Alberto, F.; Kremer, A.; Gerber, S. Species relative abundance and direction of introgression in oaks. Mol. Ecol. 2009, 18, 2228-2242. [CrossRef]

101. Anderson, R.; Harrison, T. A limitation of the hybrid index using Quercus leaf characters. Southwest. Nat. 1979, $24,463-473$. [CrossRef]

102. Bacon, J.; Spellenberg, R. Hybridization in two distantly related Mexican black oaks Quercus conzattii and Quercus eduardii (Fagaceae: Quercus: Section Lobatae). SIDA Contrib. Bot. 1996, 17, 17-41. 
103. Bartlett, H. Regression of x Quercus deamii toward Quercus macrocarpa and Quercus muhlenbergii. Rhodora 1951, 53, $249-264$.

104. Jensen, R.J.; DePiero, R.; Smith, B. Vegetative characters, population variation and the hybrid origin of Quercus ellipsoidalis. Am. Midl. Nat. 1984, 111, 364-370. [CrossRef]

105. Jensen, J. A preliminary numerical analysis of the red oak complex in Michigan and Wisconsin. Taxon 1997, 26, 399-407. [CrossRef]

106. Rushton, B. Natural hybridization within the genus Quercus L. Ann. Sci. For. 1993, 50, 73s-90s. [CrossRef]

107. Ortego, J.; Gugger, P.F.; Riordan, E.C.; Sork, V.L. Influence of climatic niche suitability and geographical overlap on hybridization patterns among southern Californian oaks. J. Biogeogr. 2014, 41, 1895-1908. [CrossRef]

108. Craft, K.J.; Ashley, M.V.; Koenig, W.D. Limited hybridization between Quercus lobata and Quercus douglasii (Fagaceae) in a mixed stand in central coastal California. Am. J. Bot. 2002, 89, 1792-1798. [CrossRef] [PubMed]

109. Ramos-Ortiz, S.; Oyama, K.; Rodríguez-Correa, H.; González-Rodríguez, A. Geographic structure of genetic and phenotypic variation in the hybrid zone between Quercus affinis and Q. laurina in Mexico. Plant Species Biol. 2016, 31, 219-232. [CrossRef]

110. Rellstab, C.; Bühler, A.; Graf, R.; Folly, C.; Gugerli, F. Using joint multivariate analyses of leaf morphology and molecular-genetic markers for taxon identification in three hybridizing European white oak species (Quercus spp.). Ann. For. Sci. 2016, 73, 669-679. [CrossRef]

111. Yücedă̆, C.; Müller, M.; Gailing, O. Morphological and genetic variation in natural populations of Quercus vulcanica and Q. frainetto. Plant Syst. Evol. 2021, 307, 8. [CrossRef]

112. Fitzek, E.; Delcamp, A.; Guichoux, E.; Hahn, M.; Lobdell, M.; Hipp, A.L. A nuclear DNA barcode for eastern North American oaks and application to a study of hybridization in an Arboretum setting. Ecol. Evol. 2018, 8, 5837-5851. [CrossRef]

113. Guichoux, E.; Lagache, L.; Wagner, S.; Léger, P.; Petit, R.J. Two highly validated multiplexes (12-plex and 8-plex) for species delimitation and parentage analysis in oaks (Quercus spp.). Mol. Ecol. Resour. 2011, 11, 578-585. [CrossRef] [PubMed]

114. Lepais, O.; Gerber, S. Reproductive patterns shape introgression dynamics and species succession within the European white oak species complex. Evolution 2011, 65, 156-170. [CrossRef] [PubMed]

115. Salvini, D.; Bruschi, P.; Fineschi, S.; Grossoni, P.; Kjaer, E.D.; Vendramin, G.G. Natural hybridisation between Quercus petraea (Matt.) Liebl. and Quercus pubescens Willd. within an Italian stand as revealed by microsatellite fingerprinting. Plant Biol. 2009, 11, 758-765. [CrossRef]

116. Pritchard, J.K.; Stephens, M.; Donnelly, P. Inference of population structure using multilocus genotype data. Genetics 2000, 155, 945-959. [CrossRef]

117. Abraham, S.T.; Zaya, D.N.; Koenig, W.D.; Ashley, M.V. Interspecific and intraspecific pollination patterns of valley oak, Quercus lobata, in a mixed stand in coastal central California. Int. J. Plant Sci. 2011, 172, 691-699. [CrossRef]

118. Zhang, R.; Hipp, A.L.; Gailing, O. Sharing of chloroplast haplotypes among red oak species suggests interspecific gene flow between neighboring populations. Botany 2015, 93, 691-700. [CrossRef]

119. Muir, G.; Fleming, C.C.; Schlötterer, C. Species status of hybridizing oaks. Nature 2000, 405, 1016. [CrossRef]

120. Aldrich, P.R.; Parker, G.R.; Michler, C.H.; Romero-Severson, J. Whole-tree silvic identifications and the microsatellite genetic structure of a red oak species complex in an Indiana old-growth forest. Can. J. For. Res. 2003, 33, 2228-2237. [CrossRef]

121. Craft, K.J.; Ashley, M.V. Population differentiation among three species of white oak in northeastern Illinois. Can. J. For. Res. 2006, 36, 206-215. [CrossRef]

122. Gailing, O.; Zhang, R. Experimental evidence for selection against hybrids between two interfertile red oak species. Silvae Genet. 2019, 67, 106-110. [CrossRef]

123. Anderson, E. Introgressive Hybridization; John Wiley Sons, Inc.: New York, NY, USA, 1949.

124. Anderson, E. Hybridization of the habitat. Evolution 1948, 2, 1-9. [CrossRef]

125. Cavender-Bares, J.; Keen, A.; Miles, B. Phylogenetic structure of Floridian plant communities depends on taxonomic and spatial scale. Ecology 2006, 87, 109-122. [CrossRef]

126. Hipp, A.L.; Manos, P.S.; González-Rodríguez, A.; Hahn, M.; Kaproth, M.; McVay, J.D.; Avalos, S.V.; Cavender-Bares, J. Sympatric parallel diversification of major oak clades in the Americas and the origins of Mexican species diversity. New Phytol. 2018, 217, 439-452. [CrossRef]

127. Jensen, J.; Larsen, A.; Nielsen, L.R.; Cottrell, J. Hybridization between Quercus robur and Q. petraea in a mixed oak stand in Denmark. Ann. For. Sci. 2009, 66, 706. [CrossRef]

128. Zeng, Y.F.; Liao, W.J.; Petit, R.J.; Zhang, D.Y. Geographic variation in the structure of oak hybrid zones provides insights into the dynamics of speciation. Mol. Ecol. 2011, 20, 4995-5011. [CrossRef] [PubMed]

129. Lind-Riehl, J.F.; Gailing, O. Adaptive variation and introgression of a CONSTANS-like gene in North American red oaks. Forests 2017, 8, 3. [CrossRef]

130. Suarez-Gonzalez, A.; Lexer, C.; Cronk, Q.C.B. Adaptive introgression: A plant perspective. Biol. Lett. 2018, 14, 20170688. [CrossRef] [PubMed]

131. Li, Z.; Liu, D. ROPGEF1 and ROPGEF4 are functional regulators of ROP11 GTPase in ABA-mediated stomatal closure in Arabidopsis. FEBS Lett. 2012, 586, 1253-1258. [CrossRef]

132. Elhaddad, N.S.; Hunt, L.; Sloan, J.; Gray, J.E. Light-induced stomatal opening is affected by the guard cell protein kinase APK1b. PLoS ONE 2014, 9, e97161. [CrossRef] [PubMed]

133. Browne, L.; Wright, J.W.; Fitz-Gibbon, S.; Gugger, P.F.; Sork, V.L. Adaptational lag to temperature in valley oak (Quercus lobata) can be mitigated by genome-informed assisted gene flow. Proc. Natl. Acad. Sci. USA 2019, 116, 25179-25185. [CrossRef] [PubMed] 
134. Bodénès, C.; Chancerel, E.; Ehrenmann, F.; Kremer, A.; Plomion, C. High-density linkage mapping and distribution of segregation distortion regions in the oak genome. DNA Res. 2016, 23, 115-124. [CrossRef] [PubMed]

135. Goicoechea, P.G.; Petit, R.J.; Kremer, A. Detecting the footprints of divergent selection in oaks with linked markers. Heredity 2012, 109, 361-371. [CrossRef] [PubMed]

136. Lind-Riehl, J.F.; Sullivan, A.R.; Gailing, O. Evidence for selection on a CONSTANS-like gene between two red oak species. Ann. Bot. 2014, 113, 967-975. [CrossRef] [PubMed]

137. Beaumont, M.A.; Nichols, R.A. Evaluating loci for use in the genetic analysis of population structure. Proc. R. Soc. B Biol. Sci. 1996, 263, 1619-1626.

138. Foll, M.; Gaggiotti, O. A genome-scan method to identify selected loci appropriate for both dominant and codominant markers: A Bayesian perspective. Genetics 2008, 180, 977-993. [CrossRef]

139. Günther, T.; Coop, G. Robust identification of local adaptation from allele frequencies. Genetics 2013, 195, 205-220. [CrossRef]

140. de Villemereuil, P.; Gaggiotti, O.E. A new $\mathrm{F}_{\mathrm{ST}}$-based method to uncover local adaptation using environmental variables. Methods Ecol. Evol. 2015, 6, 1248-1258. [CrossRef]

141. Caballero, A.; Quesada, H.; Rolán-Alvarez, E. Impact of amplified fragment length polymorphism size homoplasy on the estimation of population genetic diversity and the detection of selective loci. Genetics 2008, 179, 539-554. [CrossRef]

142. Excoffier, L.; Hofer, T.; Foll, M. Detecting loci under selection in a hierarchically structured population. Heredity 2009, 103, 285-298. [CrossRef] [PubMed]

143. Flanagan, S.P.; Jones, A.G. Constraints on the $\mathrm{F}_{\mathrm{ST}}-$ Heterozygosity outlier approach. J. Hered. 2017, 108, 561-573. [CrossRef] [PubMed]

144. Forester, B.R.; Lasky, J.R.; Wagner, H.H.; Urban, D.L. Comparing methods for detecting multilocus adaptation with multivariate genotype-environment associations. Mol. Ecol. 2018, 27, 2215-2233. [CrossRef]

145. Galesloot, T.E.; Van Steen, K.; Kiemeney, L.A.L.M.; Janss, L.L.; Vermeulen, S.H. A comparison of multivariate genome-wide association methods. PLoS ONE 2014, 9, e95923. [CrossRef]

146. Martins, H.; Caye, K.; Luu, K.; Blum, M.G.B.; François, O. Identifying outlier loci in admixed and in continuous populations using ancestral population differentiation statistics. Mol. Ecol. 2016, 25, 5029-5042. [CrossRef] [PubMed]

147. Durand, J.; Bodénès, C.; Chancerel, E.; Frigerio, J.M.; Vendramin, G.; Sebastiani, F.; Buonamici, A.; Gailing, O.; Koelewijn, H.P.; Villani, F.; et al. A fast and cost-effective approach to develop and map EST-SSR markers: Oak as a case study. BMC Genom. 2010, 11, 570. [CrossRef] [PubMed]

148. Ano, M.; Katayose, Y.; Ashikari, M.; Yamanouchi, U.; Monna, L.; Fuse, T.; Baba, T.; Yamamoto, K.; Umehara, Y.; Nagamura, Y.; et al. Hd1, a major photoperiod sensitivity quantitative trait locus in rice, is closely related to the Arabidopsis flowering time gene CONSTANS. Plant. Cell 2000, 12, 2473-2483. [CrossRef]

149. Herrmann, D.; Barre, P.; Santoni, S.; Julier, B. Association of a CONSTANS-LIKE gene to flowering and height in autotetraploid alfalfa. Theor. Appl. Genet. 2010, 121, 865-876. [CrossRef]

150. Hsu, C.Y.; Adams, J.P.; No, K.; Liang, H.; Meilan, R.; Pechánová, O.; Barakat, A.; Carlson, J.E.; Page, G.P.; Yuceer, C. Overexpression of constans homologs $\mathrm{CO} 1$ and $\mathrm{CO} 2$ fails to alter normal reproductive onset and fall bud set in woody perennial poplar. PLoS ONE 2012, 7, e45448. [CrossRef]

151. Desikan, R.; Horák, J.; Chaban, C.; Mira-Rodado, V.; Witthöft, J.; Elgass, K.; Grefen, C.; Cheung, M.K.; Meixner, A.J.; Hooley, R.; et al. The histidine kinase AHK5 integrates endogenous and environmental signals in Arabidopsis guard cells. PLoS ONE 2008, 3, e2491. [CrossRef]

152. Gailing, O.; Bodénès, C.; Finkeldey, R.; Kremer, A.; Plomion, C. Genetic mapping of EST-derived simple sequence repeats (EST-SSRs) to identify QTL for leaf morphological characters in a Quercus robur full-sib family. Tree Genet. Genomes 2013, 9, 1361-1367. [CrossRef]

153. Ning, D.L.; Wu, T.; Xiao, L.J.; Ma, T.; Fang, W.L.; Dong, R.Q.; Cao, F.L. Chromosomal-level assembly of Juglans sigillata genome using Nanopore, BioNano, and Hi-C analysis. Gigascience 2020, 9, giaa006. [CrossRef] [PubMed]

154. Fonti, P.; Heller, O.; Cherubini, P.; Rigling, A.; Arend, M. Wood anatomical responses of oak saplings exposed to air warming and soil drought. Plant. Biol. 2013, 15, 210-219. [CrossRef]

155. Levy, Y.Y.; Mesnage, S.; Mylne, J.S.; Gendall, A.R.; Dean, C. Multiple roles of Arabidopsis VRN1 in vernalization and flowering time control. Science 2002, 297, 243-246. [CrossRef] [PubMed]

156. Rellstab, C.; Zoller, S.; Walthert, L.; Lesur, I.; Pluess, A.R.; Graf, R.; Bodénès, C.; Sperisen, C.; Sperisen, C.; Kremer, A.; et al. Signatures of local adaptation in candidate genes of oaks (Quercus spp.) with respect to present and future climatic conditions. Mol. Ecol. 2016, 25, 5907-5924. [CrossRef] [PubMed]

157. Alberto, F.J.; Derory, J.; Boury, C.; Frigerio, J.-M.; Zimmermann, N.E.; Kremer, A. Imprints of natural selection along environmental gradients in phenology-related genes of Quercus petraea. Genetics 2013, 195, 495-512. [CrossRef]

158. Müller, M.; Gailing, O. Abiotic genetic adaptation in the Fagaceae. Plant. Biol. 2019, 21, 783-795. [CrossRef]

159. Gailing, O. Identification of genes under divergent selection in interfertile, but ecologically divergent oaks. Bull. Transilv. Univ. Bras. Ser. II For. Wood Ind. Agric. Food Eng. 2014, 7, 1-10.

160. López de Heredia, U.; Mora-Márquez, F.; Goicoechea, P.G.; Guillardín-Calvo, L.; Simeone, M.C.; Soto, A. ddRAD sequencingbased identification of genomic boundaries and permeability in Quercus ilex and Q. suber hybrids. Front. Plant. Sci. 2020, 11, 564414. [CrossRef] 
161. Gugger, P.F.; Fitz-Gibbon, S.T.; Albarrán-Lara, A.; Wright, J.W.; Sork, V.L. Landscape genomics of Quercus lobata reveals genes involved in local climate adaptation at multiple spatial scales. Mol. Ecol. 2021, 30, 406-423. [CrossRef]

162. Cavender-Bares, J.; González-Rodríguez, A.; Eaton, D.A.R.; Hipp, A.A.L.; Beulke, A.; Manos, P.S. Phylogeny and biogeography of the American live oaks (Quercus subsection Virentes): A genomic and population genetics approach. Mol. Ecol. 2015, 24, 3668-3687. [CrossRef] [PubMed]

163. Crowl, A.A.; Manos, P.S.; McVay, J.D.; Lemmon, A.R.; Lemmon, E.M.; Hipp, A.L. Uncovering the genomic signature of ancient introgression between white oak lineages (Quercus). New Phytol. 2020, 226, 1158-1170. [CrossRef] [PubMed]

164. Crowl, A.; Bruno, E.; Hipp, A.; Manos, P. Revisiting the mystery of the Bartram oak. Arnoldia 2020, 77, 6-11.

165. Hauser, D.A.; Keuter, A.; McVay, J.D.; Hipp, A.L.; Manos, P.S. The evolution and diversification of the red oaks of the California floristic province (Quercus section Lobatae, series Agrifoliae). Am. J. Bot. 2017, 104, 1581-1595. [CrossRef]

166. Kim, B.Y.; Wei, X.; Fitz-Gibbon, S.; Lohmueller, K.E.; Ortego, J.; Gugger, P.F.; Sork, V.L. RADseq data reveal ancient, but not pervasive, introgression between Californian tree and scrub oak species (Quercus sect. Quercus: Fagaceae). Mol. Ecol. 2018, 27, 4556-4571. [CrossRef] [PubMed]

167. Ortego, J.; Gugger, P.F.; Sork, V.L. Genomic data reveal cryptic lineage diversification and introgression in Californian golden cup oaks (section Protobalanus). New Phytol. 2018, 218, 804-818. [CrossRef] [PubMed]

168. Rieseberg, L.H. Hybrid Speciation in Wild Sunflowers. Ann. Mo. Bot. Gard. 2006, 93, 34-48. [CrossRef]

169. Arnold, M.L.; Bouck, A.C.; Cornman, R.S. Verne Grant and Louisiana irises: Is there anything new under the sun? New Phytol. 2004, 161, 143-149. [CrossRef]

170. Abbott, R.; Albach, D.; Ansell, S.; Arntzen, J.W.; Baird, S.J.E.; Bierne, N.; Boughman, J.; Brelsford, A.; Buerkle, C.A.; Buggs, R.; et al. Hybridization and speciation. J. Evol. Biol. 2013, 26, 229-246. [CrossRef] [PubMed] 